\title{
Os santos nos faxinais: religiosidade e povos tradicionais
}

\author{
Antonio Paulo Benatte, José Adilçon Campigoto e Rosenaldo de Carvalho
}

\section{RESUMO}

Este artigo discute as relaçôes que povos tradicionais - os faxinalenses - estabelecem com o sobrenatural, analisando suas rezas, celebrações e devoções a São João, ao Divino Espírito Santo e a São Roque. Pretende-se dar visibilidade à cultura dessas populaçóes rurais organizadas em torno do uso comum de recursos naturais, notadamente as pastagens, na região Sul e Centro-Sul do Estado do Paraná. O exame dessas relaçóes permite-nos observar aspectos dessa tradição, como as curas e benzeduras de animais, o conhecimento das plantas medicinais, a demarcação dos espaços, as relações com o tempo, a simbologia do trabalho e do descanso dos animais, as rezas e as festas, o cotidiano e o extraordinário.

Palavras-chave: faxinal; povos tradicionais; religiosidade; Paraná; Brasil.

\begin{abstract}
This article discusses the relationships that traditional people - the faxinalenses - have with the supernatural, analyzing their prayers, celebrations and devotions to St. John, the Divine Holy Spirit and St. Roque. It is intended to give visibility to the rural culture of these communities organized around the common use of natural resources, especially the pastures, in the South and South-Central Parana State. The review of these relationships allows us to observe aspects of this tradition, like healings and benedictions of animals, the knowledge of medicinal plants, the demarcation of the spaces, the relationships with time, the symbolism of the work and the rest of the animals, prayers and festivals, the daily life and the extraordinary.
\end{abstract}

Keywords: faxinal; traditional people; religion; Parana; Brazil. 
As culturas dos povos tradicionais podem ser consideradas como partes características de um campo de estudos relativamente novo no âmbito da escrita da história, talvez por conta da carga polissêmica do termo "cultura" e, também, devido à difícil definição da categoria "povo"; além disso, como bem lembrou Paul Little, a expressão "tradicional" geralmente é associada a concepçóes imobilistas da história e considerada fator de atraso econômico" ${ }^{1}$.

A noção de povos tradicionais, entretanto, será aqui considerada como categoria analítica capaz de conjugar alguns fatores importantes para a produçáo do saber histórico no contexto da diversidade cultural brasileira. Será uma noção central neste artigo, posto que, em se tratando da área rural, combina aspectos como a existência de regimes de propriedade comum, o sentido de pertencimento a um lugar, a busca de autonomia cultural e certas práticas adaptativas sustentáveis que os grupos sociais levam a efeito na atualidade ${ }^{2}$. Este conhecimento inicial nos permitirá cotejar os faxinais ${ }^{3}$ enquanto parte da diversidade fundiária do Brasil, vislumbrando três pontos fundamentais: o regime de propriedade comum, o sentido de pertencimento a um lugar específico e a dimensão histórica da ocupação conservada na memória coletiva ${ }^{4}$.

Podemos considerar que o uso socializado das terras, a idéia da pertença e a memória comum são características notáveis na história da ocupação territorial da região centro-sul do estado do Paraná, onde estão situados os chamados faxinais. $\mathrm{O}$ faxinal, além de ser um tipo de paisagem existente na regiáo sul do Brasil, caracteriza-se como uma forma de organização própria dos agricultores dessa região, um modo de vida que, conforme dizem os próprios faxinalenses, "existe para mais de cem anos". A origem dos faxinais, pode-se dizer, perdeu-se na imprecisão da memória comum ; mas os faxinalenses, assim como os babaçueiros, os caboclos, os caiçaras, os caipiras, os campeiros, os jangadeiros, os pantaneiros, os pescadores artesanais, os praieiros, os sertanejos e os varjeiros, sáo considerados povos tradicionais. E isso porque, em 2005, foram integrados, por lei, à Comissão Nacional de Desenvolvimento Sustentável dos Povos e Comunidades Tradicionais. Conforme a legislação em vigor no Brasil ${ }^{6}$, trata-se de grupos culturalmente diferenciados e que se reconhecem como tais, possuindo formas próprias de organização social. Esses agrupamentos de pessoas ocupam territórios, aproveitando recursos naturais como condição para a sua "reprodução" cultural, social, religiosa, ancestral e econômica. Ainda conforme o decreto, tais grupos utilizam-se de conhecimentos, inovaçôes e práticas gerados e transmitidos pela tradição.

A definição contida em lei vincula ensinamento e tradição, perspectiva que seguiremos neste artigo, por estar em concordância com a proposta hermenêutica gadameriana, nosso principal referencial teórico ${ }^{7}$. A tradição será, pois, concebida como ação que “... realiza-se por gestos criativos e livres de reconhecimento e transmissão de princípios civilizacionais" ${ }^{8}$. Deve ficar claro, portanto, que a tradição não é o conteúdo transmitido, mas o próprio ato de transmitir, que é parte da cultura, outra noção chave delimitada a seguir.

Alguns historiadores dos séculos XIX, como Jacob Burckhardt e Johan Huizinga, trabalharam com temas como evolução de culturas, civilização e barbárie. Suas reflexóes foram marcadas pelo caráter eminentemente ocidental e eurocêntrico, sendo a Europa concebida como a parte civilizada do mundo e, por isso mesmo, cabendo aos europeus a missão de levar a cultura aos outros povos do planeta. Nessa perspectiva, a escrita da história seria, basicamente, o registro desse movimento de "transmissão da cultura", do centro para a periferia". Ademais, no que tange às técnicas e métodos historiográficos, os historiadores metódicos partiam do pressuposto de que, através da crítica documental, chegar-se-ia à pureza dos fatos, ou seja, seria possível reconstruir o "acontecimento" tal como ocorreu. Essa noção de documento histórico como dado objetivo implicava a tese de que a história se produz a partir de textos escritos, lançando às margens da história os povos ágrafos e todos os setores sociais que não utilizam sistemas de escrita ou recorrem pouco a eles. Em consonância com essa concepção grafológica e grafocrática de história, a noção de documento marcava o lugar de irradiação da cultura, o conteúdo a ser transmitido. 
A reflexão gadameriana sobre a criação e a transmissão de saberes implica que a comunicação não se dá a partir de um centro onde se deposita a tradição, pois a tradição é a própria transmissão, e essa é largamente descentrada e multilinear ${ }^{10}$. Dessa forma, a tradiçẫo está (também) nas periferias, pois ali os conhecimentos também são constantemente transmitidos e retransmitidos. Podemos falar, portanto, em história dos povos tradicionais, estejam eles inseridos ou não na cultura escrita.

Esses grupos, também chamados marginais, foram, por muito tempo, excluídos da história; mas, nas últimas décadas, como se sabe, a história escrita a partir do centro e da figura dos grandes heróis foi amplamente questionada pelos defensores da nova historiografia, em ruptura com a visão eurocêntrica e etnocêntrica da "grande narrativa" da civilização ocidental. A nova história fez emergir novos objetos, temas e sujeitos para o campo da pesquisa histórica, abrindo-se para o diálogo com as ciências sociais, em especial a antropologia. Assim, costuma-se dizer que não existem mais espaços interditados à escrita da história, ou seja, que tudo pode ser "historiado": a economia, a sociedade, a política e, inclusive, a cultura. E entramos aqui no campo da história cultural.

Peter Burke, num esforço para melhor delimitar esse campo do conhecimento, afirma que "o terreno comum dos historiadores culturais pode ser descrito como a preocupação com o simbólico e suas interpretaçôes. Símbolos, conceitos ou não, podem ser encontrados em todos os lugares, da arte à vida cotidiana"11. A definição de Burke, no entanto, nos parece muito genérica, uma vez que vários pesquisadores de outras áreas investigam o simbólico e suas representaçôes. Mesmo assim, entendemos que:

O campo do simbólico é o locus onde se operam as lutas e os conflitos sobre os significados acerca das práticas sociais, da vida e da morte. Tais disputas têm tanta importância como os conflitos econômicos... As disputas simbólicas mobilizam e sensibilizam afetos. Motivam sociabilidades e promovem embates que são travados em várias esferas da sociedade. ${ }^{12}$

Para ser mais específico, e com o objetivo de focalizar mais precisamente a cultura dos povos faxinalenses, o simbólico será compreendido aqui como linguagem, ou seja, como lugar em que o fenômeno cultural se dá a conhecer. A cultura é compreendida, então, como um conjunto de relaçóes "(...) que o sujeito estabelece com a natureza e com o meio em que vive e com o sobrenatural (...)"13. Assim, entendemos as devoçóes aos santos - o tema deste artigo - como um tipo de relaçáo que os faxinalenses estabelecem com o mundo sobrenatural. Nosso interesse sobre essa prática religiosa visa à compreensão da cultura faxinalense ${ }^{14} \mathrm{e}$ à reunião de conhecimentos para a escrita da história desses povos tradicionais.

As relaçóes com o sobrenatural na religiosidade popular do Brasil colônia foram estudadas por Laura de Mello e Souza, entre outros historiadores. A historiadora identifica os seguintes canais de comunicação dos indivíduos com o mundo "imaginário": os sonhos, as metamorfoses, os sabás, as possessôes, os calundus e os catimbós. Essa relação com o sobrenatural, que incluía as visôes celestiais e as visões infernais, segundo Laura de Mello e Souza, “(...) são imprescindíveis à compreensão do que foi a formaçáo social do Brasil colônia" ${ }^{15}$. Consideramos, igualmente, que o entendimento das devoçôes populares ligadas ao catolicismo é fundamental para a compreensão da cultura dos faxinalenses. Segundo André Luiz da Silva,

Desde [os estudos do sociólogo] Procópio Camargo, na década de 60, tem-se falado muito a respeito do catolicismo, mas do catolicismo enquanto instituição: os temas abordados giram em torno das questóes de poder, das relaçôes da Igreja com o Estado e com a política. Esta dificuldade aumenta quando se procura por trabalhos sobre devoçóes populares; porém, a julgar pela produção recente (...) este quadro tem se alterado. ${ }^{16}$

Essas devoçôes populares constituem um campo de interesse de muitos investigadores no âmbito da história e das ciências das religióes; por isso mesmo, será preciso definir melhor o nosso interesse a respeito das religiosidades dos faxinalenses. Primeiramente, é necessário informar que as relaçôes dos 
habitantes dos faxinais com o sobrenatural serão aqui tomadas não da maneira como o fez boa parte dos etnólogos do século XIX, quando esta disciplina estruturou-se. Aquele tipo de etnologia, de acordo com Jaqueline Hermann, "dedicou-se a inventariar costumes e práticas das chamadas "sociedades naturais", em que, na quase totalidade dos casos, a determinação religiosa parecia oferecer uma chave importante, senão fundamental, para a organização e o funcionamento destes grupos primitivos" ${ }^{17}$.

Trata-se de um ponto a ser lembrado porque esse estudo sobre as devoçôes aos santos nos faxinais não tem como objetivo desvelar o funcionamento das organizaçóes dos faxinalenses e muito menos se vale daquelas classificaçôes que empregavam categorias como sociedades naturais, grupos primitivos, ou noçôes semelhantes. A exclusão de tal aparato conceitual nos permite delimitar o campo de estudos e, como recompensa, contornar as teses derivadas do positivismo e do evolucionismo, como as do antropólogo britânico Edward Burnett Tylor, segundo o qual "para o homem primitivo, tudo é dotado de alma, o que explicaria o culto aos mortos e aos antepassados, além do nascimento dos deuses", e que essa "era a característica original da criação religiosa, passando do politeísmo ao monoteísmo, ponto máximo de um processo de evolução espiritual" ${ }^{18}$.

O culto aos santos, tal como tratado neste artigo, não será relacionado aos ritos fúnebres praticados nos faxinais, o que mereceria um estudo à parte; nem estabeleceremos conexóes com o nascimento das divindades ou com as discussóes oitocentistas sobre o animismo, porque não há aqui nenhuma pretensão de buscar a origem nem de perseguir a evolução de traços religiosos nas longas duraçôes da história, da "noite dos tempos" até os faxinais. Além disso, vale salientar que essas devoçôes serão aqui tratadas enquanto elementos pertencentes ao campo da religiáo, embora possam apresentar caracteres semelhantes ao que se chamava de magia ou "pensamento mágico" entre os antropólogos do final do século XIX e início do $\mathrm{XX}^{19}$.

É necessário esclarecer que escritores e estudiosos regionais, desde os anos 1970, associaram a religiosidade faxinalense a formas de culto que remeteriam às idades míticas. Foed Castro Chamma, por exemplo, classificava a cultura dos agricultores como um modo de vida baseado em temores míticos que se expressa pelo recurso às divindades para obter a proteção das colheitas. Em uma perspectiva racionalista e "progressista", ele observou que

A realidade agrária (...) começa já a se ressentir de uma ação que irá modificar substancialmente o panorama econômico e cultural do país em futuro muito próximo. Trata-se de um trabalho do governo visando uma orientação racional para o agricultor na assimilação de fatores científicos que permitam o desenvolvimento de suas culturas agropecuárias fora daquele temor sacramentado por um culto que vem de idades mitológicas, quando Ceres era evocada, e eram rendidos sacrifícios em favor da deusa para a proteção das colheitas. ${ }^{20}$

Ora, a busca de proteção e de soluçôes para certas dificuldades enfrentadas no cotidiano dos faxinais, nas práticas devocionais relacionadas principalmente à saúde das pessoas e dos animais, à colheita e ao tempo bom, ou seja, ao clima favorável à agricultura e à pecuária, é um aspecto dessa religiosidade que pode ser traduzida como uma espécie de culto doméstico. Na mesma regiáo em que Chamma pressupôs detectar resíduos de culturas "irracionais" percebe-se que cada família, adotando um santo padroeiro, assume como que uma espécie de obrigaçáo de fazer o festejo para o seu protetor, no dia a ele dedicado em uma espécie de calendário litúrgico informal. Também na década de 70, José Maria Orreda, sobre a localidade de Riozinho ${ }^{21}$, registrou que era obrigação

(...) festejar Santa Cruz na casa de Nho Salvador, no viaduto... E São João, no reduto de D. Maria Elisa; na morada de João Ferreira Camargo, vizinho de João Catanduva, Santo Antônio; São Pedro reunia o povo na casa de Pedro Soares; e São Sebastião, no bungalow de José Freitas dos Santos. ${ }^{22}$

É importante lembrar que os moradores do Riozinho organizaram-se sob a forma de faxinal, pelo menos até a primeira década do século XX, quando o espaço do criadouro comum foi atravessado pela 
Estrada de Ferro São Paulo-Rio Grande ${ }^{23}$. Mas, com base no texto de Orreda, podemos sustentar que a prática de "festejar o santo em casa" continuou, mesmo com a dissolução daquele faxinal. Isso nos leva a considerar que as mudanças na cultura não seguem, necessariamente, o ritmo das modificaçóes nas formas de organização social ou produtiva.

O dia da festa do santo é acatado, atualmente, como dia santo em muitos faxinais, evidenciando certa característica peculiar em relação aos ensinamentos oficiais do catolicismo, segundo os quais dias santificados são domingos e os outros dias de festa de preceito, segundo o calendário eclesiástico. Oficialmente, nessas datas os fiéis devem abster-se de atividades e outros negócios que impeçam o culto a ser prestado a Deus.

Tal definição, como se vê, é sumária e diz respeito ao culto à divindade e não aos santos. $\mathrm{O}$ direito canônico, no entanto, dilata a conceituação, prescrevendo que os dias santos de guarda dos cristãos católicos são os domingos, o Natal, a Ascensão de Jesus Cristo, a Ascensão de Maria, o dia de São José, o dos Apóstolos Pedro e Paulo, e por fim, o dia de Todos os Santos. Mas, a Conferência Nacional dos Bispos do Brasil não considera o dia de São José (19 de março) como dia santo.

Constata-se, portanto, certo dissenso entre as instâncias da Igreja Católica quanto ao assunto, ao passo que o calendário dos dias santos faxinalenses, numa primeira aproximação, parece igualar dia santo e dia dedicado ao santo. Então, essa forma de devoção pode ser considerada como popular e leiga, uma vez que segue orientação e dinâmica diversa daquela preconizada pelo catolicismo oficial.

Os depoimentos dos faxinalenses evidenciam que o número de dias santificados nos faxinais é muito maior do que os que se encontram nos calendários eclesiásticos oficiais. Conforme Darci de Carvalho, morador do faxinal de São João da Palmeirinha, dias santos

existem vários, na realidade: dia do Divino Espírito Santo, Santo Antônio, São João, Saao Bom Jesus, Sant'Ana... Bastante dia santo que nós guardávamos. São José, São Roque... Alguns, no momento, eu não lembro... Que no sistema antigo era tudo diferente: que hoje não tem mais. Hoje em dia mudou muito. Meu pai ensinava no ritmo dos antigos os dias santos. Era só... ${ }^{24}$

O "sistema antigo" a que ele se refere pode ser interpretado como um conjunto de práticas relacionadas ao catolicismo implantado no Brasil a partir de Portugal, ou seja, o catolicismo do Brasil colônia. Sobre esse tema, Vera Jurkevics ressalta que

A implantação do catolicismo no Brasil refletiu, de um modo geral, as muitas práticas que integravam a cultura religiosa portuguesa marcada por uma tradição medieval, que ainda não havia absorvido a reforma tridentina, em curso, em boa parte da Europa (...). Mesmo lá, demorou muito tempo até que fosse estabelecida uma uniformidade em torno das decisóes conciliares, uma vez que, durante o século XVI, as paróquias não chegavam a ser verdadeiramente importantes na religiosidade vivida por aquelas populaçóes e que, no século seguinte, duas práticas coabitavam na cristandade do Velho Mundo: a do clero e a dos fiéis... ${ }^{25}$

Outros estudos sobre o tema, igualmente, nos levam a considerar que o Concílio de Trento (15451563) teve maiores repercussões em assuntos como a hierarquia eclesiástica, a padronização das práticas do clero e a administração de sacramentos. Por outro lado, alguns rituais e celebraçôes, tais como o batismo, o casamento e a morte, acabaram sendo regulados e submetidos à criatividade das populaçôes locais, tanto em Portugal, como no Brasil.

Tal capacidade criadora fortemente vinculada ao passado - ao "sistema antigo" - gerou um conjunto de práticas piedosas, devocionais e festivas de caráter mais individual que comunitário, nas quais a comunicação com a divindade é, geralmente, intermediada pela figura do santo ${ }^{26}$. Além disso, haveria certa ênfase na visibilidade ritualística manifesta, por exemplo, nas novenas, nas trezenas, nas rezas fortes, nas romarias, nas plantaçóes dos mastros, nas cantorias, nas danças devocionais e nas procissóes ${ }^{27}$. Afirma-se que esse tipo de religiosidade estaria relacionado ao Portugal dos séculos XVI e XVII, funda- 
mentando-se na estrutura agrária "latifundiária" e na sociedade patriarcal, então vigentes no país. Naquele ambiente religioso, como sustenta o sociólogo José Arthur Rios, "por toda parte, as imagens de santos povoam nichos, nos cantos das ruas, em altares, oratórios e capelas, dentro das casas e, como o culto à Virgem, animam festas, romarias e procissóes, grandes manifestaçóes coletivas que se vão repetir no Novo Mundo"28. A religiosidade descrita por Rios identifica-se, a princípio, com os "esquemas" da vida religiosa desenvolvidos em torno dos engenhos, mas não, inteiramente, tendo em vista os povos tradicionais. Podemos pressupor que este aspecto individualista e "privatista" seria mais evidente em espaços tais como o dos engenhos, e menos efetivo em ambientes como os territórios faxinalenses.

É preciso notar, em concordância com Laura de Mello e Souza, que o catolicismo dos engenhos, ligado ao "familismo", com capelães sob o comando do senhor de engenho, conforme apontado por Gilberto Freyre, "relega as manifestações indígenas às matas sombrias e as africanas à insalubridade das senzalas" ${ }^{29}$. Evidentemente, a realidade social, econômica, política e cultural dos faxinais diferencia-se em muito da dos engenhos; além disso, essa realidade é bastante diferente das reduçôes e dos chamados quilombos.

Os faxinais representam uma realidade distinta das apontadas acima, pois não se organizaram em torno de um latifundiário, senhor de terras e de escravos, tal como ocorria nos engenhos de açúcar; também não se constituíram a partir das reduçóes indígenas, ou de antigos quilombos, ou de outros redutos de enfrentamento ao regime estabelecido ${ }^{30}$. Será, então, necessário pensar essas práticas religiosas desenvolvidas nessas situaçôes em que o poder das oligarquias locais não era táo presente, nem os conflitos com a sociedade circundante táo marcadamente abertos. Mesmo assim, pode-se dizer que o recurso à proteçáo dos santos era comum e assinalado por uma "unidade familiar", doméstica ou semi-doméstica. Pressupomos que há nisso uma marca característica dos "regimes antigos" e dos modos tradicionais de experiência do sagrado.

Em estudo sobre a implantação do catolicismo no Brasil, Eduardo Hoornaert partiu da premissa de que "o catolicismo brasileiro assumiu (...) um caráter obrigatório" ${ }^{31}$, destacando o caráter ostensivo das práticas religiosas em questão. O realce é importante, embora concordemos com a observação de Mello e Souza de que os estudos eleborados por Hoornaert não contemplam a "característica básica da nossa religiosidade de então: justamente o seu caráter especificamente colonial. Branca, negra, indígena, refundiu espiritualidades diversas em um todo absolutamente específico e simultaneamente multifacetado"32. Retemos do estudo de Hoornaert, entretanto, a tese de que era praticamente impossível viver na colônia sem respeitar ou adotar a religiáo católica. Tal situação se deveria aos seguintes elementos:

Quando no decorrer do século dezoito, o movimento comercial no Brasil começava a interessar a muita gente, a Inquisição não ficou desinteressada e começou a deportar "cristãos-novos" ricos para Portugal com subseqüente confisco dos bens no Brasil (...) Diante desse clima de medo criado pelas denunciaçóes, visitaçôes, deportaçóes, repressôes e confiscos, os brasileiros reagiram de maneira inteligente: criaram um catolicismo ostensivo, patente aos olhos de todos, praticado, sobretudo em lugares públicos, bem pronunciados e cheios de invocaçóes ortodoxas a Deus, Nossa Senhora e aos santos. ${ }^{33}$

Ostentar publicamente o santo de devoção significava, portanto, valer-se de um escudo protetor. Estar sob o amparo de alguma dessas figuras reconhecidas, demonstrando que sua casa e sua família eram devotadas a alguma dessas entidades, significava uma chance de não sofrer acusaçóes de heresia ou de descrença, ou ainda, de práticas pagás tais como a bruxaria. Esse clima "fanfarrista" adotado pelos leigos na religiosidade colonial pode estar na base do que se tem chamado de catolicismo "santeiro" e na prática das plantaçóes de mastros e de cruzeiros, assim como nas rezas organizadas pelos devotos de santos. É o caso dos faxinais.

Evidentemente, a atividade do Tribunal do Santo Oficio não será identificada como a explicação para a ostensiva religiosidade dos faxinais. Isto seria de um anacronismo absurdo. Mas é notório o caráter privado dessas práticas. Há, nos faxinais, muitas daquelas características que, na senda de 
Gilberto Freyre, Luiz Mott localizou em seu estudo sobre as vivências religiosas no período colonial. De acordo com ele

Cada devoto montava "sua" corte celeste privativa: seu anjo da guarda, seus santos protetores prediletos. Nosso Senhor e a Virgem Maria com suas várias invocaçôes. Os quadros de milagres e ex-votos conservados nos santuários e templos mais populares refletem muito bem a relação íntima e respeitosa dos fiéis com seus oragos, verdadeiras tábuas de salvação nos momentos dramáticos dessa sociedade tão desassistida das artes médicas. ${ }^{34}$

A devoção as santos nos faxinais, como já apontamos, relaciona-se à cura das doenças, ao alívio das dores, ao enfrentamento das dificuldades, à proteção diante dos perigos, ao controle das forças do infortúnio e à falta de assistência por parte das instâncias políticas e religiosas. A historiografia relativa ao assunto nos permite pressupor que a iniciativa popular, frente à ausência da hierarquia, resultou na produção de um catolicismo "moreno" (a expressão é de Hoornaert), mestiço e considerado popular. José Roberto Lopes, por exemplo, afirma o seguinte:

Situados como intermediários nessa mão dupla da relação entre o homem e Deus - ora instrumentos dos milagres benéficos, ora dos maléficos - os santos passam a possuir um status dogmático, o qual a Igreja utiliza para firmar sua hegemonia. Daí em diante, cresce a distância entre os santos canonizados e os "santos" populares, relegados à periferia das zonas institucionais de produção do ethos religioso. Essa dicotomia marca profundamente a ambigüidade do santoral católico popular, que oscila regularmente entre uns e outros. Tal oscilação pode ser constatada nas insistentes reivindicaçóes populares pela canonização de santos que não se enquadram no status dogmático estabelecido pela Igreja, como também pelas produçóes de características populares atribuídas aos santos canonizados segundo aqueles dogmas. ${ }^{35}$

A produção do próprio santo, a escolha da entidade protetora ou do patrono da família - e, ainda, de boa parte das formas de homenageá-lo, isto é, dessa liturgia popular -, tem sido considerada como efeito dos longos períodos de ausência do clero nesses espaços rurais geralmente distantes dos aglomerados populacionais citadinos. Distante dos centros urbanos, a prática de rituais e de celebraçóes mais importantes - como o batismo, o matrimônio, a morte - eram regulados e submetidos à criatividade dos praticantes. Mutatis mutandis, as populaçóes faxinalenses de São João da Palmeirinha, São Pedro e Rio Azul dos Soares viveram uma história análoga de inventividade religiosa.

Conforme o registro histórico oficial da Matriz do Sagrado Coração de Jesus, instalada no município de Rio Azul, a regiáo somente passou a contar com os serviços de párocos residentes a partir de meados da década de 1960; mas os fiéis eram atendidos pelos padres em suas visitas pastorais. Ivan Gapinski informa que os missionários do Verbo Divino atendiam a regiáo desde 1900 e que

.... p primeira capela da cidade foi construída no ano de 1910. Afirma-se que a iniciativa coube a um devoto de São Sebastião, José Lúcio da Silva. Media oito metros de largura por doze de comprimento, construída em madeira e coberta com tábuas lascadas. Mais tarde, no ano de 1929, iniciou-se a construçáo da segunda igreja, concluída seis anos mais tarde, no ano de 1935. Onze anos mais tarde, construiu-se um novo templo, sendo a atual igreja matriz, construção de 1978. Como se vê, a própria história da construção dos templos católicos na região, no início do século XX, está vinculada às devoçôes populares e à iniciativa do laicato. ${ }^{36}$

Com base em alguns documentos, nota-se que esses padres deslocavam-se de cidades vizinhas tais como Guarapuava, distante cerca de 130 quilômetros; de Palmeira, distante 100 quilômetros; e de São João do Triunfo, que distava 60 quilômetros de São João da Palmeirinha. Estas "aparições” pastorais eram feitas de três em três meses, totalizando apenas quatro "visitas" durante o ano, situação que perdurou até a década de 1960. Podemos afirmar que tal condição abria ampla margem de espaço para práticas leigas e que, portanto, elas não eram incomuns na regiáo. Celso Vianna Bezerra de Meneses revela que, na área em que se desenrolou a guerra do Contestado, "testemunhas dão conta de inúmeros 
rezadores e curadores que percorriam as regióes interioranas cumprindo as funçôes religiosas à falta de padres que as fizessem". Informa, ainda, que "antes de 1850, notícias seguras dáo conta da presença de três monges na região" 37 .

Vários pesquisadores pressupóem que um desses monges, João Maria de Agostinho, teria percorrido o caminho das tropas que ligava Sorocaba, em São Paulo, a Santa Maria, no Rio Grande do Sul, na época das mineraçóes. O monge teria instituído, na localidade de Campestre, uma série de serviços religiosos que perduraram no tempo, como veremos adiante. Casos como este levam a presumir com mais convicção que a ausência de ministros oficiais fazia com que os leigos se sentissem na obrigação de organizar as rezas e de assumir algumas funçóes religiosas, assim como os monges e seus seguidores o fizeram. Esses leigos eram conhecidos como capeláes e suas atividades, segundo depoimento dos moradores do faxinal, resumiam-se a coordenar e capitanear as rezas dos dias santos e dos terços, além de oficializar a encomenda dos corpos, sempre que ocorriam falecimentos de pessoas pertencentes à comunidade.

Os capelães eram considerados como detentores do conhecimento religioso, isto é, dos modos de fazer, como diz o ex-morador do faxinal, Delfino de Oliveira Bueno: “(...) é que nós íamos assistir as festas lá (...) Tinha mastro, tinha bandeira do Divino, e todo mundo ia cantando; e nosso professor era o tal do Chico Correia (...)" ${ }^{38}$. Delfino afirma que Francisco Correia conhecia as oraçóes, os cânticos religiosos e sabia fazer as rezas do modo correto, ou seja, conforme a necessidade de cada momento. Uma das ocasióes mais importantes para os capeláes exercerem tais habilidades e demonstrarem seus préstimos eram os velórios. Diante do morto, era preciso organizar ritualmente os terços, os cânticos fúnebres e a encomenda do corpo. Realizava-se, entáo, aquele conjunto de "gestos criativos e livres de reconhecimento" e a "transmissão de princípios" da cultura religiosa local.

Mas os ritos fúnebres representam apenas um dos muitos serviços religiosos efetuados pelos capelãesmestres leigos nos territórios faxinalenses. Franciane Gurski refere-se, por exemplo, às cerimônias de batismo realizadas nos faxinais. Trata-se de uma forma ritual não praticada necessariamente pelo capelão, mas que ilustra a atuação dos leigos também nessas funçóes, objetos de controle eclesiástico. Gurski destaca que no faxinal da Palmeirinha, assim como em outros, localizados nas imediaçóes, realizam-se

batismos paralelos aos das igrejas institucionalizadas, sendo necessária uma espécie de iniciaçáo com o seguinte trâmite... Pessoas acometidas de qualquer doença fazem a promessa de que, sendo curadas, se batizarão no olho de São João Maria. Essas fontes, espalhadas pelos três estados do sul do Brasil, são considerados como lugares onde o santo parou para descansar de suas andanças e tomar água. Nestas ocasiôes sempre plantava uma cruz e abençoava o lugar para que essas vertentes nunca secassem. ${ }^{39}$

As práticas efetivadas em torno dos olhos d'água de São João Maria ${ }^{40}$ ilustram bem as funçôes religiosas exercidas na região dos faxinais. Essas funçôes são ainda mais evidentes no âmbito do ofício das rezas, pois que o próprio monge-santo ensinava a organizar celebraçôes, tornando-se, com o tempo, alvo ele próprio das comemoraçóes no calendário religioso dos faxinalenses. Robinson Fernando Alves descreveu a celebração da romaria de Santo Antão, em Campestre, no interior do Rio Grande do Sul, instituída, ao que parece, pelo próprio monge mediante um documento intitulado Aos do Campestre, no qual, segundo Robinson,

Fica evidente (...) a organização da confraria. João Maria é assessorado por doze zeladores em seus trabalhos, em clara sintonia com Jesus Cristo, que escolhe doze apóstolos quando inicia sua vida pública. Para a continuidade do culto, o eremita designa, da mesma forma, um procurador para substituí-lo na diligência dos zeladores. ${ }^{41}$

O culto estabelecido dessa forma evidencia claramente a existência de um ciclo comemorativo religioso paralelo ao oficial, marcado por novenas, romarias, rezas e festas aos santos padroeiros. Os 
capelães e seus ajudantes são os responsáveis pela organização destes eventos, tais como os realizados em honra a São João ${ }^{42}$. Sáo João é, ao que parece, um dos santos mais reverenciados pelos habitantes dos faxinais. José Gomes de Oliveira, morador do faxinal, lembra que esta comemoração é realizada há muito tempo. E informa que

...a festa de São João aqui era uma reza, na verdade; entấo, vinha gente vender mimosa... Um trazia uma galinha para o santo; um trazia um quilo de feijão; um quilo de batata doce; um quilo de mandioca; daí punha aquilo no leilão e arrecadava aquele dinheirinho para o santo; e não tinha despesa nenhuma... ${ }^{43}$

Note-se que Oliveira não qualifica as comemoraçóes de São João como festas, talvez porque, na cultura cabocla, esse tipo de evento tenha um sentido bem específico. Vejamos os termos empregados para designá-los. Conforme o "dicionário caboclo" elaborado por José Júlio Cleto da Silva ${ }^{44}$, pagode e festança significam folia, desordem e bebedeira, ao passo que farra, farrancho e súcia indicam reunião de homens solteiros. Charivari, fecha e rebuliço equivalem à briga, conflito, agitaçáo. Todos esses termos remetem, evidentemente, à dimensão do profano. Sintomaticamente, parece não haver "designativo específico para as festas religiosas ou caseiras" $\$ 5$.

As comemorações de São João são classificadas como rezas, ou seja, uma forma de devoção, uma maneira de agradecer e fazer pedidos ao santo, práticas que se alongavam por mais de uma semana. A preparaçáo do evento começava, geralmente, nove dias antes do acontecimento principal e "(...) cada um se encarregava de fazer a novena, ajudava o santo (...)" ${ }^{46}$. Os encarregados da festa sáo aqueles indivíduos que se colocaram ou foram colocados sob a proteção da entidade, pois quando uma criança é batizada, sendo homônima de santo, este será seu padrinho, isto é, protetor perpétuo no plano espiritual. As pessoas da família, ou seja, da casa em que se realiza a função, encarregam-se de realizar o "novenário". A confraternizaçáo, após a última novena, é destinada a arrecadar fundos para a festa do ano seguinte. Organiza-se uma espécie de leiláo em que se vendem mercadorias doadas pelos participantes da reza que, às vezes, compram-nas de volta "para ajudar o santo". José Gomes de Oliveira, referindo-se especificamente à festa de São João da Palmeirinha, narra que "todos os que compareciam tinham sempre algo a oferecer (...): uma galinha, um quilo de feijáo, um quilo de batata doce" 47 .

Ainda de acordo com a narrativa de Oliveira, na noite que antecedia ao dia do santo, era preparada a fogueira; a última novena era entáo realizada, na parte da manhã do dia 24 de junho. A cerimônia, geralmente, iniciava-se com uma procissão, durante a qual era hasteado o mastro com a imagem do santo e, logo após, feitas as rezas no interior da residência. A confecçáo do mastro e da bandeira é considerada, por vários depoentes, como um acontecimento merecedor de atençâo especial. Rememorando os detalhes, Oliveira conta que

(...) derrubavam um pinheirinho, farquejavam ${ }^{48}$ e deixavam igual a um vigote ${ }^{49}$; os homens que pintavam eram meus compadres; já são mortos, também. Daí, riscavam com uma régua e marcavam. A tinta nós comprávamos e eles pintavam. Um de uma cor e outro de outra. Um quadrinho, assim colorido... A bandeira? A gente comprava o pano e fazia a bandeira; e daí, pregava no mastro; e na hora da reza, pegava e erguia o mastro. Fazia um buraco e fincava aquele mastro; isso era todo dia 24 de São João; 24 de junho, dia de São João... ${ }^{50}$

A bandeira e o mastro, de fato, podem ser analisados como elementos significativos do rito e estão vinculados a antigas práticas populares que, no faxinal de São Pedro, por exemplo, persistiram mesmo quando a reza deixou de ser praticada nas casas para realizar-se na capela. No faxinal, a bandeira e o mastro de Santo estão associados à cruz e aos cruzeiros, como se verá mais adiante. O mastro, no entanto, é um elemento marcante da festa. Delfino Oliveira Bueno, morador daquele faxinal, afirma que, por causa da modificação do lugar em que ocorria o evento, as novenas e a organização da festa ficaram a cargo do capelão, "homem muito antigo... Chico Correia..." 51 . Mesmo realizado no espaço 
institucional da igreja, o evento "também tinha festa de São João; tinha o tal mastro, do mesmo jeito. Aí a festa tinha churrasco, aquela coisa... era ali no São Pedro" ${ }^{52}$. Mas, significativamente, os depoentes consideram que a reza nas casas era mais original.

José Gomes de Oliveira, do Faxinal do Rio Azul dos Soares, e Darci de Carvalho, do Faxinal do Saltinho, município de Rebouças, declaram que as confraternizaçóes realizadas nas casas, depois das rezas e das novenas, eram animadas, com a diferença de que, ali, não ocorriam brigas. Portanto, nem charivari, nem fecha, nem rebuliço. Tratava-se mesmo de uma reza, prática piedosa e sagrada. Em alguns casos raros, no entanto, mesmo esses encontros caseiros se aproximavam das fechas, porque eram "festas grandes":

Vinha parente, vinham os amigos. Reunia-se muita gente, aqui. O gramadão ficava cheio; aí vinha gente do Faxinal dos Paulo; gente a escambau; gente da Invernada; praticamente, vinha gente de quase todo o município de Rio Azul; vinham um ou dois... sempre, então, tinha gente. ${ }^{53}$

O "gramadão" é apresentado como o espaço de realização do evento. Trata-se de um ambiente peculiar, quando o território é organizado em sistema de faxinal, porque é parte da área de compáscuo, esse amplo recinto cercado composto por matas e pastagens. No interior dessa estância, localizam-se as habitaçôes dos faxinalenses; ali também são criados animais de várias espécies, tais como bovinos, eqüinos, caprinos, ovinos e suínos, além de vários tipos de aves domésticas. Soltos no grande cercado, esses animais alimentam-se da grama existente, de pequenos arbustos e dos frutos nativos tais como a gabiroba, a cereja e o pinhão. Os proprietários dos animais dão-lhes uma suplementação alimentar nos períodos de maior escassez. As casas são dispostas no interior da área cercada, várias protegidas por um cercado menor, em torno do qual as criaçóes circulam livremente.

O tempo de uso e os cuidados dos moradores com a limpeza da área faz com que a grama se alastre até as áreas cobertas pela vegetação menos densa. Como essas festas são realizadas em casas de família, geralmente construídas para abrigar apenas seus membros, o gramado passa a ser ocupado nesses dias de grande fluxo de pessoas. Pode-se dizer que, nesses dias santos, o espírito da festa invade o faxinal. Mas, os gramados não são lugares demarcados e ordenados previamente; são espaços de circulação livre, principalmente dos animais; e, nos dias de festa, dependendo do santo, é necessário definir os caminhos por onde se deve carregar o mastro. Trata-se da demarcação dos percursos das procissôes, uma característica a destacar na festa do Divino Espírito Santo, por exemplo.

Essa reza do 10 de Maio é nomeada de "procissão do Divino". Os moradores do faxinal referem-se ao festejo como um evento do passado, composto por uma seqüência de nove dias de celebraçóes, isto é, de novenas. Depois de cada uma delas, o dono da casa servia licores, café e chimarrão, aos capelães e aos participantes em geral. Conforme rememora Darci de Carvalho, "cada casa tinha um encarregado de fazer a novena. Aí, no décimo dia, tinha festa, que era costume a festa do Divino Espírito Santo. Era formada a festa, geralmente, depois do almoço" ${ }^{54}$. Como o homenageado dessas rezas e louvaçôes tratava-se de um integrante da trindade santa, elas eram realizadas no período diurno e raramente eram promovidas por afilhados de santo, como no caso das rezas de São João. Assim, também náo aconteciam os leilóes e as ofertas de donativos; mas, havia a cerimônia da confecção do mastro, com a bandeira do Divino; no décimo dia, a procissão, com rezas e cantorias ${ }^{55}$.

A comitiva seguia por pequenas passarelas, como se fossem ruas, preparadas especificamente para este fim, contornando a casa onde estava sendo organizada a reza. Segundo o depoente, "antes da reza fazia-se uma procissão; preparavam o mastro, faziam passarelas com pimenteiras, faziam as ruazinhas para entrar e sair da festa" ${ }^{16}$. Essas passagens efêmeras eram demarcadas cortando-se pequenos ramos e até árvores, tais como a pimenteira, planta típica e abundante nessas regióes. Após a procissão, realizava-se uma parada, na frente da casa, ao som das cantorias, quando se atingia o ponto culminante da celebração, isto é, o levantamento do mastro com a bandeira. Fazia-se um buraco e fincava-se o mastro. 
Em seguida, todos se voltavam para o interior da casa, para o cômodo em que estivesse localizado o altar (geralmente a sala), a fim de procederem às últimas oraçôes. Integrava, também, os rituais a prática de enrolar-se na bandeira, ou seja, o fiel aproximava-se e, segurando uma das pontas do estandarte, dava uma volta no corpo, envolvendo-se nela. Essa parte dos ritos, porém, não era seguida em todos os lugares. Mas, um preceito rigorosamente observado dispunha que nenhuma bebida alcoólica, exceto o licor, fosse servida nesse festejo.

O consumo do licor parece ser uma concessão tardia e própria da região dos faxinais, pois, conforme Franciane Gurski, tais aperitivos servidos nestas ocasióes "eram fabricados pelas faxinalenses":

Feitos de amoras pretas silvestres e cascas de laranjas cozidas com açúcar e aguardente, resultavam em deliciosos licores. A utilização de licores nas festas parece fugir ao que seria o modelo de festa recomendada pelo monge em documento transcrito por Romeu Beltrão, intitulado como Aos do Campestre. Seria uma carta escrita pelo monge aos seus seguidores na capela de Santo Antão do Campestre, nas proximidades de Santa Maria, Rio Grande do Sul, em meados do século XIX. No texto o autor recomenda que sejam responsáveis para administrar a festa e proíbe o uso de licores. ${ }^{57}$

O uso dessa bebida indica que a devoção foi sofrendo modificaçóes; ou seja, que mesmo a reza considerada como parte do "sistema antigo" modificou-se em relação ao que foi considerado como conselho do monge. Darci de Carvalho conta que, no faxinal, depois da festa, passavam a tarde conversando, comendo bolo, tomando licor até que todos iam para suas casas. Restava ao chefe da família reorganizar o ambiente para o retorno ao tempo normal, ao cotidiano. O mastro ficaria ali plantado até a data da reza do próximo ano, quando seria substituído por outro. Podemos, então, supor que o mastro demarca o tempo das rezas, tempo cíclico, assim como o é o calendário das celebraçôes cristãs, em geral.

Uma das funçôes básicas do calendário consiste em marcar o ritmo das interposiçôes entre o trabalho e o tempo livre, isto é, o entrelaçamento desses dois tempos. Para Jacques Le Goff, o tempo do trabalho é regular, linear, mais propenso às mutaçôes históricas, enquanto o tempo cíclico é mais tradicional e menos permeável a elas ${ }^{58}$. O calendário litúrgico católico é mais que um almanaque de festas ${ }^{59}$ : pode também ser considerado como um demarcador de tempo, pois que os festejos mais importantes da espiritualidade católica estáo ali definidos, tratando-se de um ciclo completo. Do mesmo modo, o calendário santoral pode ser pensado como parte dos esquemas oficiais de repetiçáo, posto que o dia dedicado a um determinado santo repete-se todos os anos.

No meio popular, assim como nos faxinais, uma celebração pode ser introduzida quando uma criança é batizada com o nome de um santo. São Roque, por exemplo, não faz parte do calendário oficial como dia de preceito; mas, no faxinal seu dia é considerado como um momento de guarda e de oraçóes. Além disso, a benesse de não se trabalhar durante esse dia se estende aos animais. Conforme os depoimentos, nessa data, em hipótese alguma, os animais de tração eram utilizados para realizar serviços costumeiros, tais como lavrar a terra, puxar veículos, arrastar ou transportar objetos, ou carregar pessoas. Palminor Brito narra que “(...) nós guardávamos toda vida; eu, até agora guardo o dia de São Roque. O pai mandava tirar até o cincerro dos cavalos. Só dava milho. Agora não... Andam a cavalo... Judiam... Maior pecado judiar do bicho no seu dia" ${ }^{\prime 0}$.

Em outras palavras, o depoente enuncia um conflito simbólico entre dois tempos. No passado, na era de São Roque, os animais de tração e montaria tinham uma data dedicada a eles. Isto não significava, apenas, a sua não utilização por um dia. Tratava-se, mais profundamente, de uma relação específica estabelecida entre os faxinalenses e o rebanho, evidenciada pelo ato de retirar o cincerro dos cavalos. Ora, essa espécie de sino é um recurso de grande valia nos faxinais, uma vez que os animais são livres para percorrer a extensa área de compáscuo. O som emitido pela sineta atada ao pescoço do animal facilita a sua localização, trabalho que, sem esse recurso, pode levar horas. Retirar o cincerro significa 
libertá-lo, deixá-lo livre e sem jugo algum. A relação entre o santo e o animal, neste caso, é de libertação, pelo menos por um dia.

As analogias que se estabelecem entre santos, animais e demônios levaram José Rogério Lopes a sustentar que

São Bartolomeu, São Jorge, São Roque e São Lázaro são exemplos de imagens que, em suas figuraçôes, são associadas a demônios e a cachorros, respectivamente, gerando uma dupla devoção - em uma dialética entre negação-afirmação, ou em uma dupla afirmação. Se essa dupla devoção não foi aceita pela estrutura eclesiástica do catolicismo, por outro lado, essa mesma duplicidade foi incorporada posteriormente pelos cultos sincréticos de origem afro, como na umbanda brasileira. ${ }^{61}$

A associação entre os santos e os animais, no entanto, parece ter como contraponto a relação entre os animais e os fiéis. Christiane Alves afirma que, em certos terreiros afros por ela estudados,

(...) durante aproximadamente três dias, ao som de tambores (...), os cães são servidos por fiéis, como se fossem seres humanos. O processo consiste em servir os pratos no chão sobre uma toalha bordada, como uma mesa, e na cabeceira é colocada uma imagem do santo homenageado. Serve-se normalmente arroz, carne, macarrão, galinha e salada, entre outras. Essa mesma comida é servida às pessoas que participam do ritual, e estas se alimentam somente depois dos cães, servindo-se do mesmo tipo de alimento. Alguns promesseiros chegam a comer na posição de cachorro, sem talheres e com a boca no prato. Há casos até em que o cão e o fiel comem no mesmo prato. A origem do ritual não é conhecida, mas ele é organizado por devotos de São Lázaro e São Roque (ambos os santos são associados aos animais, principalmente aos cães) e promesseiros que queiram reconhecer uma graça alcançada. Realizado em sítios, casa ou terreiros de culto afro, esse ritual consiste em agradar uma criatura que teve uma importância na vida desses homens. Agradando-se aos cães, agrada-se ao santo. ${ }^{62}$

Com se pode notar, nessa mesa ritual os animais e os seres humanos são dispostos no mesmo nível de valoraçáo frente ao santo. Pode-se dizer, então, que na realização do rito o santo separa-se do mundo, em oposição ao tempo em que ainda era vivo. O vínculo entre Roque - enquanto sujeito vivente (antes de morrer e tornar-se santo) - e os cães é bem conhecido na hagiografia católica. Conforme esta versão de sua biografia,

Roque nasceu em Montpellier, na França, em 1295... Perdeu os pais entre os quinze e vinte anos, herdando um enorme patrimônio... Repartiu entre os pobres, em segredo, tudo o que pôde colher de suas rendas... Partindo sem nada para Roma, mendigando pelo caminho. Chegando a Toscana, em Aguapendente, viu a grande mortalidade causada pela peste. Levado pelo desejo de ser útil aos empestados, pediu permissão ao administrador do hospital para assistir aos doentes, o que lhe foi permitido. Em Piacenza (Palencia), acabou por contrair a doença... Para não perturbar com seus gritos os outros doentes do hospital, dirigiu-se para fora da cidade, à entrada de um bosque, onde encontrou uma pequena choça que lhe serviu de abrigo... Roque viu brotar perto da cabana, um manancial de água cristalina... Se não fosse um cão que todos os dias lhe trazia páo roubado da mesa do dono, teria morrido de fome. $\mathrm{O}$ dono do cáo, intrigado com a regularidade com que este lhe roubava o pão, seguiu-o certa vez, pela floresta, encontrando Roque, de quem se tornou amigo... Roque foi curado e voltou para a França. ${ }^{63}$

Observa-se, então, que a vinculação, tão explícita nos faxinais, com os animais de carga, de montaria e de tração é estranha à biografia de Roque. Poderíamos supor que a prática de não empregar os animais no trabalho, nesse dia, seria própria dos faxinais, ou pelo menos da região das matas de araucária $^{64}$, dos caboclos do Contestado, dos monges, dos tropeiros e dos Campos Gerais ${ }^{65}$. A confluência desses elementos sugere haver alguma relação com a cultura dos tropeiros ${ }^{66}$, um dos aspectos explorados pelo turismo religioso na regiáo ${ }^{67}$. A imagem de Sáo Roque pode evocar tropeiros e 
monges devido ao seu aspecto de andarilho e ao chapéu de aba larga. Essa figura, amplamente reverenciada no faxinal, tem, unicamente para si, um dia de guarda, sendo homenageado com novena e festa, ou melhor, com as rezas faxinalenses.

As oraçôes dedicadas a São Roque são variadas e, de forma geral, invocam a proteção contra a peste e a cura de doenças contagiosas ${ }^{68}$. Essa especialização taumatúrgica do santo, evidentemente, não constitui uma idiossincrasia faxinalense; ademais, ela frequentemente aparece misturada a práticas e crenças de outras proveniências. Por exemplo, no poema Osparaníadas, em seu Canto III, intitulado "Epopéia das lendas", Francisco Pereira da Silva refere-se às "crendices" dos habitantes da Ilha do Mel, em torno da Pedra do Mestre da Barca; São Roque é mencionado, ao lado de dois outros santos, nos seguintes versos:

Sabei, na Ilha do Mel, uma pedra havia

que feridas malignas curava.

Todo o enfermo que a ela recorria, encostar-se na pedra só bastava.

E fazendo-o, o povo repetia

o que antiga crendice lhe ensinava:

"São Cipriano, São Bento, São Roque,

fazei com que isso não volte a reboque!" ${ }^{9}$

No caso da devoção a São Roque, exaltam-se as virtudes altruísticas e curativas do santo, relacionando-o aos médicos, aos enfermeiros e aos atendentes de hospitais. Em geral, parece haver um vínculo exclusivo com as doenças e a saúde dos seres humanos, distanciando-o, desta vez, de qualquer relação com os animais; mas em algumas versóes, inclusive nas que são pronunciadas nos faxinais, invoca-se a proteção contra a peste e as enfermidades dos animais domésticos, como na seguinte oração:

Ó São Roque, tu que deixaste a tranqüilidade do lar e foste socorrer os doentes. Não recuaste nem mesmo diante da peste e da morte. Lembra-te de nós e socorre-nos com igual amor. Defende as nossas criaçôes da peste e da doença. Dá-nos saúde, paz na família e espírito comunitário. Fortalece em nós a fé e a esperança, na presença de Deus que nos encoraja, na construção de um mundo humano e justo. Concede-nos estas graças, pelos méritos de Jesus Cristo, com o qual partilhaste a dor e o sofrimento e que agora vive com o Pai, na unidade do Espírito Santo. Amém! ${ }^{70}$

Criaçôes é termo corrente utilizado pelos faxinalenses para referir-se aos animais domesticados; mas, conforme o dicionário de gíria cabocla, diz-se bicharedo para indicar "grupos ou pontas de gado", enquanto bicharia significa indivíduo ou objeto bonito, e ainda tropa gorda. Os animais bravios, e ntretanto, recebem o designativo de bichedo ${ }^{71}$. Pode-se afirmar, então, que o termo bicho, assim como seus derivados, aplica-se aos animais selvagens e aos domésticos de grande porte. $\mathrm{O}$ sistema do faxinal, no entanto, abriga também o gado menor. Conforme Cicilian Luiza Löwen Sahr e Luiz Alexandre Gonçalves Cunha, "neste espaço o uso da terra é coletivo, mas a propriedade sobre a terra continua sendo privada. Aí se encontra o gado miúdo (principalmente porcos) e o gado graúdo (cavalos, bois)"72. A reunião de tantos animais exige manejos contra a ameaça de doenças, cuidado que inclui uma série de conhecimentos relacionados à saúde animal. A reza de São Roque era uma delas, mas outros conhecimentos também eram mobilizados.

José Maria Orreda registrou que, na década de 1970, Pacífico Ferreira, morador do Rio Bonito, atualmente bairro da cidade de Irati ${ }^{73}$, casado com Leontina, era curandeiro e benzedor e ensinava os remédios e as simpatias para as enfermidades que acometiam os animais. Dizia que garrotilho se cura com

casca de catáia,/ ubre empedrada de vaca, lavar efusão folha guabirobeira, ou pau de leite/ rabuge, casca de ipê e pau raposa, folha de pimenteira cozida/ peste de galinha e boba, folha de cedro do mato na água/ 
remediar golpe no lombo de animal, carvão pau-de-Andrade,/ congestão ou sangue na cabeça, sangrar no pescoço/ animal pesteado, semente de cinamomo/ fortalecer osso, sal/ alisar o pelo e calmante, açúcar/ espantar pulga, palma fedida/ derrubar bichas de terneiro, folha de pessegueiro/ verme, cipó tayuyá/ rabuge de cadela, limáo e pólvora, enxofre com banha/ curar aftosa, creolina ou simpatia recortar casco na terra e rezar, cortar casco em cruz recomenda Toribinho na Barra Mansa/ mordidura de cobra, socar palma fedida, arruda e alho, azeite e urina/ bexiga, passar chinelo de mulher na barriga em cruz e salsa cozida/ lombrigão, hortelã socada/ bicheira, pó folha de pessegueiro/ bexiga, chá de pico-pico/ derrubar berne, animal na direção do sol poente passar vassoura do rabo à cabeça. ${ }^{74}$

Assim como se fala da medicina popular - e na regiáo das tropeadas, da medicina tropeira - é possível constatar a existência de uma veterinária popular praticada nos faxinais e adjacências. Essa arte do tratamento de doenças dos animais congrega um conjunto de saberes e conhecimentos sobre ervas medicinais, procedimentos terapêuticos e processos de encantamento. No fragmento acima, percebe-se uma série de nomes de plantas e de designativos para doenças, dominados pelo curandeiro e, até certo ponto, pelas pessoas que conduzem seus animais em busca de remédios do mundo natural e sobrenatural. Esses saberes populares náo são, evidentemente, exclusivos da região dos faxinais ${ }^{75}$; mas, Paulo Barros dos Santos, benzedor e curandeiro de animais, habitante do faxinal do Sáo João, ensina a seguinte fórmula que, segundo ele, será mais eficaz quando pronunciada por pessoa devota do santo:

São Roque e sua santidade passando por aqui trazendo o seu poder e o dom da cura para todas as criaçóes, contra as pestes, as larvas, feridas e a todos os animais que sofrem alguma conseqüência. Sáo Roque, eu agradecerei este pedido; em nome de vós serei atendido. ${ }^{76}$

Como se pode perceber, não se trata de pedir proteção ao santo, pois não se trata de uma prática preventiva: a fórmula refere-se à cura, isto é, ao fechamento de feridas, à extinção de larvas e ao fim da peste. Aliás, peste é um termo que merece atenção por sua generalidade. Conforme se lê em Gíria cabocla do sul do Paraná, "peste" é, também, indivíduo ruim, que tem maus sentimentos, intrigante e falador; além disso, designa piolhos, pulgas, larvas e parasitas que, em geral, atacam os animais. Mas, animalejos tais como porcos ou aves silvestres que atacam as plantaçóes, também são considerados como pestes, recebendo o nome de "imundície"77. São Roque é invocado contra as ditas "conseqüências". O depoente Paulo Barros dos Santos relata que, na época das rezas de São Roque,

Era muito pequeno, naquela época, muito pequeno, mas eu andava junto com a falecida minha avó... Então nós andávamos todos juntos. Eu, na época, quando eles faziam aquelas rezadas... Acho que eu tinha uns seis ou oito anos. Eu era matraqueiro; aquele que batia a matraquinha. Para sair nas casas e fazer as rezadas... A Semana Santa inteirinha, sabe? Era feita a rezada nas casas. Só as casas que não tivessem... Olhe! Só a casa que não tivesse a cruz no portão, nós não podíamos chegar. Nós éramos proibidos de chegar porque ali nós respeitávamos; porque, ali, não é para nós chegarmos. Nós só chegávamos nas casas que tinham cruz. ${ }^{78}$

A cruz, segundo ele, representava um marco, um sinal ostensivo de que os rezadores seriam recebidos. $\mathrm{O}$ matraqueiro afirma que a cruz era o sinal de um pacto baseado numa interpretação particular de um preceito por eles vinculado à Bíblia. Paulo Barros dos Santos informa que a cruz no portáo da casa simbolizava

(...) uma palavra bíblica que diz assim: "Maldito o homem que comercializa as terras". E aí, então, pela crença que eles tinham, que eles ficavam com aquela terra prometida, assim para não vender para ninguém, e ficava doado para um filho, um neto. Assim que funcionava. Daí, eles punham a cruz, jurando para Deus que eles náo iam ser aquele maldito homem que comercializa as terras, entendeu? Assim que funciona... A vicinal que cada um ia fazer a sua. Aí, então, eles repartiam as colônias, botavam a cruz e cada colônia tinha sua cruz. ${ }^{79}$ 
Numa dessas colônias, chamada Invernada, conforme o depoente, toda a área era propriedade de seu avô, que doou muita prenda, inclusive terras, para São Roque.

Tudo ali era terreno do meu avô. Entấo, foi doado... E sempre o avô falava que, para as criaçóes ir bem... Então quando dava festa nós, cada um, levávamos um cabrito para o leilăo, lá para a festa, para São Roque. São Roque, porque ali naquela igreja de Santo Antônio, ali tem o São Roque. É o protetor das criaçóes da Invernada... ${ }^{80}$

Mas depreende-se que as terras não foram doadas à Igreja por acreditar-se que as oraçôes feitas num lugar oficial fossem mais bem aceitas. Paulo Barros dos Santos afirma que as rezas,

aonde você fizesse era bem aceito. Se você reunisse sua família dentro da casa, vamos dizer, eu, o pai, a mãe, os irmão, todos ali reunidos, temos uma criação doente, vamos fazer nossa oração de São Roque. Ali nós ia se reunir, rezar terço, tudo o que eles pediam para São Roque. No outro dia, nos já tínhamos o retorno. A criação tava boa. ${ }^{81}$

A reza extraordinária - ou seja, aquela realizada em casos de emergência, ou sempre que a necessidade impusesse - seguia, conforme o depoimento, um ritmo mais livre, autônomo, enquanto a reza anual, realizada no dia do santo, era regularizada pela alternância dos que a promoviam. Nas palavras de Paulo Barros dos Santos:

Vamos dizer, você é o devoto. Você vai fazer na tua casa; então, você vai fazer sete anos. Daí muda para mim. Daí, eu faço sete anos. Daí, vai para outro, e ele vai fazer sete anos. Você fez sete anos, cumpriu a sua [obrigação]. Assim que funcionava naquela época. Agora, quinem agora, os padres já mudaram foram mudando, mudando... ${ }^{82}$

A título de conclusáo, podemos dizer que o culto aos santos, na medida em que fazem parte das relaçôes que os faxinalenses estabelecem com o mundo sobrenatural, integram e constituem, portanto, a cultura faxinalense. Nos faxinais estudados, e conforme os depoimentos de alguns de seus moradores, as antigas práticas sofreram modificaçôes, adaptações e influências diversas. As rezas realizadas nas casas das famílias visavam a cura e a proteção contra as doenças das pessoas e dos animais. É o caso da devoção a São Roque, que incluía um dia de folga para os animais de tração e montaria; um tipo de relação, por assim dizer, de equivalência entre os seres humanos e os animais. As virtudes de Sáo Roque associam-se a antigos saberes relativos à fitoterapia animal, ao conhecimento de ervas medicinais, ao pronunciamento de fórmulas e à prática de gestos que teriam, de acordo coma tradição, propriedades curativas. As rezas de São Roque evocam a memória dos cruzeiros plantados nas vicinais, dos mastros e dos ramos de pimenteira que demarcam espaços e caminhos para a passagem do cortejo do Divino, circundando a casa do devoto. Os caminhos de ramos da pimenteira desenham-se no gramado em que se tomam os licores outrora asceticamente proibidos por São João Maria, monge do Contestado, também reverenciado nos faxinais com fogueira, mastro e bandeira. $\mathrm{O}$ mastro marca o ciclo do tempo, pois se houver batismo no olho d'água de alguma criança com o nome de João, Roque, Divino ou outro santo, ele poderá tornar-se festeiro na tradição dos faxinais.

\section{Notas}

${ }^{1}$ LITTLE, Paul E. Territórios sociais e povos tradicionais no Brasil: por uma antropologia da territorialidade. Brasília, Universidade de Brasília, 2002. Disponível em: <http://www.unb.br/ics/dan/Serie322empdf.pdf> Acesso em 23 de março de 2010 .

${ }^{2}$ Ver LITTLE, Paul E. Territórios sociais e povos tradicionais no Brasil: por uma antropologia da territorialidade, op. cit. 


\begin{abstract}
${ }^{3}$ Chama-se sistema de faxinais a certo modo de utilização das terras em comum, delimitada por cercado, para a criação de animais, existente na região sul do Brasil e que se tem classificado como manifestaçáo cultural dos povos tradicionais. Assim, o faxinal é dividido em terras de criar - ou área de compáscuo -, um cercado composto por matas e pastagens em que se localizam as habitaçóes dos faxinalenses. Na parte interior a essa área comum, que pode pertencer a um proprietário não morador do faxinal ou a vários proprietários, são criados animais de várias espécies, tais como bovinos, eqüinos, caprinos, ovinos e suínos, além de vários tipos de aves domésticas. Soltos no grande cercado, esses animais alimentam-se da grama existente, de pequenos arbustos e dos frutos nativos tais como a gabiroba, a cereja e, principalmente, o pinhão. Os donos dos animais lhes oferecem suplementação alimentar nos períodos de maior escassez. As casas são dispostas no interior da área cercada, sendo boa parte delas protegida por um cercado menor, ao entorno dos quais as criaçóes circulam livremente. As entradas e saídas destas áreas são protegidas por porteiras e cancelas ou por uma espécie de pequenas pontes construídas sobre um vão seco, escavado especialmente para tal fim. Esses artefatos, chamados de mata-burros, são construídos intercalando-se uma prancha e um vão, de modo que as pessoas e os automóveis possam transitar sem a necessidade de abrir porteiras, enquanto que os animais os evitam. As terras de plantar localizam-se fora do cercado e podem pertencer ao proprietário que as cultiva ou serem arrendadas. O sistema de faxinal pode ser facilmente vinculado à frente oriental paranaense de extração da erva mate e à cultura da criação de suínos em sistema extensivo, praticado nesta região desde o século XVII. Como já mencionado, os coletores de erva mate, quando viam escasseando os recursos do lugar em que estavam instalados, adentravam a mata, transportando consigo os apetrechos de que necessitavam, os recursos alimentícios e alguns animais para transportar carga e para o consumo.
\end{abstract}

${ }^{4}$ Ver LITTLE, Paul E. Territórios sociais e povos tradicionais no Brasil: por uma antropologia da territorialidade, op. cit.

${ }^{5}$ Ver CAMPIGOTO, José Adilçon; BONA, Aldo Nelson. A hermenêutica e a origem dos faxinais. Revista de História Regional, v. 14, n. 2, 2009. p. 127-153.

${ }^{6}$ BRASIL. Decreto no. 6040, de 7/02/2007.

${ }^{7} \mathrm{Na}$ perspectiva hermenêutica filosófica de Hans-Georg Gadamer, tradição é sinônimo de transmissão.

${ }^{8}$ CÔRTES, Norma. Descaminhos do método: notas sobre história e tradição em Hans-Georg Gadamer. Varia Historia, Belo Horizonte, n. 36, v. 22, jul.-dez. 2006., p. 15.

${ }^{9}$ Nota-se, aqui, que a cultura é concebida como conteúdo transmitido.

${ }^{10}$ Ver GADAMER, Hans-Georg. Verdade e método: traços fundamentais de uma hermenêutica filosófica. Petrópolis: Vozes, 1999.

${ }^{11}$ Apud SOCHODOLAK, Hélio e CAMPIGOTO, José Adilçon. Estudos em história cultural na região sul do Paraná. Guarapuava: Unicentro, 2008. p. 16.

${ }^{12}$ Idem, p. 17.

${ }^{13}$ Idem, p. 19.

${ }^{14}$ Não discutiremos aqui o conceito de cultura popular. O leitor pode consultar, sobre o assunto, o trabalho de Mikhail Bakhtin em que se aplica o conceito de "circularidade cultural", ou seja, a existência de um relacionamento circular, feito de alternâncias, em que os elementos se movem, ora de cima para baixo, ora na direção oposta (BAKHTIN, Mikhail. A cultura popular na Idade Média e no Renascimento: o contexto de François Rabelais. Sáo Paulo: Annablume/Hucitec, 2002). Dessa forma, Bakhtin abriu novas perspectivas para se pensar em outros modos de articulação entre as práticas e o mundo social, "sensíveis à pluralidade das clivagens que atravessam os grupos sociais, rompendo o tradicional paradigma da dicotomia entre o erudito e o popular”. Ver JURKEVICS, Vera Irene. Os santos da igreja e os santos do povo: devoçóes e manifestaçóes de religiosidade popular. Tese (Doutorado em História) - Universidade Federal do Paraná, Curitiba, 2004. p. 2.

${ }^{15}$ MELLO E SOUZA, Laura de. O diabo na terra de santa cruz: feitiçaria e religiosidade popular no Brasil colônia. São Paulo: Companhia das Letras, 1986. p. 245.

16 SILVA, André Luiz da. Devoçóes populares no Brasil: contextualizando algumas obras das ciências sociais. Revista de Estudos da Religião, n. 3, 2003, p. 30-49. Disponível em <http://www.pucsp.br/rever/rv3_2003/p_silva.pdf>

${ }^{17}$ HERMANN, Jaqueline. História das religiōes e religiosidades. In: CARDOSO, Ciro Flamarion; VAINFAS, Ronaldo (Orgs.). Dominios da história: ensaios de teoria e metodologia. Rio de Janeiro: Campus, 1997. p. 330.

${ }^{18}$ Apud HERMANN, Jaqueline. História das religióes e religiosidades, op. cit., p. 331.

${ }^{19}$ Consideramos como digressão necessária esta nota sobre a magia, pois qualquer aproximação à prática das desobrigas nos conduz aos limiares do que os antropólogos designaram com este termo. O antropólogo James George Frazer, por exemplo, afirma que "O homem primitivo, vivendo no primeiro tempo de sua história, acreditava que as regras da magia eram idênticas às da natureza, o que o levava a esperar uma resposta adequada e imediata da natureza para a soluçáo de suas dificuldades". Apud HERMANN, Jaqueline. História das religióes e religiosidades, op. cit., p. 331.

${ }^{20}$ CHAMMA, Foed Castro. Notas para um estudo da ecologia de Irati. Revista Irati - Sexagésimo aniversário do município. Irati, 1967. p. 93. 
${ }^{21}$ Riozinho, atualmente um bairro da cidade de Irati (PR).

${ }^{22}$ ORREDA, José Maria. Irati. Irati, PR: Editora Sul-Oeste do Paraná Ltda., 1981. p. 151.

${ }^{23}$ Estrada de ferro com $1.403 \mathrm{~km}$ de extensão, entre Itararé (SP) e Santa Maria (RS), projetada pelo engenheiro João Teixeira Soares, em 1887, para ligar as províncias de São Paulo, Paraná, Santa Catarina e Rio Grande do Sul pelo interior. No Paraná, a estrada atravessou o estado no sentido norte-sul e está relacionada à guerra do Contestado.

${ }^{24}$ Entrevista concedida por Darci de Carvalho a Rosenaldo de Carvalho em 04/04/2009.

${ }^{25}$ JURKEVICS, Vera Irene. Os santos da igreja e os santos do povo, op. cit., p. 25.

${ }^{26}$ Idem, p 26.

${ }^{27}$ Idem, ibidem.

${ }^{28}$ RIOS, José Arthur. Sentimento religioso no Brasil. In: JURKEVICS, Vera Irene. Os santos da igreja e os santos do povo, op. cit., p.27.

${ }^{29}$ MELLO E SOUZA, Laura de. O diabo na terra de santa cruz, op. cit., p 87.

30 Às vezes, associam-se os faxinais às reduçóes guaraníticas no aspecto do uso da terra comum; também, pode-se estabelecer relaçóes entre os faxinais e os quilombos, uma vez que alguns faxinais da região organizaram-se em torno do criatório comum, e que, no município da Lapa, por exemplo, há uma localidade chamada de Faxinal dos Pretos. Além disso, é bem provável que alguns redutos de caboclos, durante a guerra do Contestado, tenham funcionado, também, em torno do criatório comum. Os faxinais, no entanto, náo estão vinculados necessariamente a realidades de conflito aberto. Em alguns casos, estão relacionados à imigração ucraniana e polonesa e ao acesso a recursos naturais, principalmente à água.

${ }^{31}$ HOORNAERT, Eduardo. Formação do catolicismo brasileiro: 1550-1800. Petrópolis: Vozes, 1978. p. 13.

32 MELLO E SOUZA, Laura de. O diabo na terra de santa cruz, op. cit., p. 88.

${ }^{33}$ HOORNAERT, Eduardo. Formação do catolicismo brasileiro, op. cit., p. 16.

${ }^{34}$ MOTT, Luiz. Cotidiano e vivência religiosa: entre a capela e o calundu. In: MELLO E SOUZA, Laura de. História da vida privada no Brasil: cotidiano e vida privada na América Portuguesa. Sáo Paulo: Cia. das Letras, 1997. v. 1. p 137.

${ }^{35}$ LOPES, José Roberto. Imagens e devoçôes no catolicismo brasileiro: fundamentos metodológicos e perspectivas de investigaçóes. Revista de Estudos da Religião, n. 3, 2003, p. 1-29. Disponível em <www.pucsp.br/rever/rv3_2003/p_lopes.pdf 18> Acesso em 15/04/2011.

${ }^{36}$ GAPINSKI, Ivan; CAMPIGOTO, José Adilçon. A dança de São Gonçalo nos faxinais de Rio Azul/PR. Tempo, Espaço e Linguagem (TEL), v. 1, n. 3, set.-dez. 2010, p. 59.

${ }^{37}$ MENESES, Celso Vianna Bezerra de. Religióes e práticas religiosas na região do Contestado. Tese (Doutorado em Antropologia Social) - Universidade de São Paulo, São Paulo, 2009. Disponível em

<http://www.teses.usp.br/teses/disponiveis/8/8134/tde-08092009-163215/pt-br.php>

${ }^{38}$ Entrevista concedida por Delfino de Oliveira Bueno a Rosenaldo de Carvalho em 09/04/2009.

${ }^{39}$ GURSKI, Franciane. Os olhos d água e a festa de São João Maria no faxinal Palmeirinha. Trabalho de Conclusão de Curso (Graduação em História) - Universidade Estadual do Centro-Oeste (Unicentro), Irati, 2009. p. 3.

${ }^{40}$ A figura dos monges relaciona-se à guerra do Contestado. Segundo Tonon, a confusão no imaginário sobre a distinção dos vários monges decorre também dos homônimos: o primeiro chama-se João Maria D’Agostini; o segundo, identificando-se como o antecessor, dizia-se chamar João Maria de Jesus de Santo Agostinho, e o terceiro fazendo-se conhecer como José Maria de Santo Agostinho, apresentava-se como irmão do segundo. Os dois primeiros usam o nome João; os três utilizam o prenome Maria. Para os sertanejos, há apenas um monge: São João Maria. Ver TONON, Eloy. Os monges do Contestado: permanências históricas de longa duração das prediçôes e rituais no imaginário coletivo. Tese (Doutorado em História) Universidade Federal do Rio de Janeiro, Rio de Janeiro, 2008. p. 98-99.

${ }^{41}$ ALVES, Robinson Fernando. O monge João Maria de Agostinho em Campestre, Santa Maria: aspectos históricos. Debates do NER, Porto Alegre, ano 11, n. 17, jan.-jun. 2010. p 53.

${ }^{42}$ Os capelães eram auxiliados por assistentes que, aos poucos, iam aprendendo o ofício para substituir os que ficavam impedidos de fazê-lo por motivo de doença ou morte.

${ }^{43}$ Entrevista concedida por José Gomes de Oliveira a Rosenaldo de Carvalho em 04/04/2009.

${ }^{44}$ SILVA, José Júlio Cleto da. Gíria cabocla do sul do Paraná. Curitiba: Imprensa Oficial do Estado do Paraná, s/d.

${ }^{45}$ CAMPIGOTO, José Adilçon. A tragédia e a festa: São João da Palmeirinha, Rio Azul (PR). In: SOCHODOLAK, Hélio; ANTUNES, Jair. História e tragicidade. São Paulo: Scortecci, 2010. p. 110.

${ }^{46}$ Entrevista concedida por José Gomes de Oliveira a Rosenaldo de Carvalho em 04/04/2009.

${ }^{47}$ Idem. 
Os SANTOS NOS FAXINAIS: RELIGIOSIDADE E POVOS TRADICIONAIS

Antonio Paulo Benatte, José Adilçon Campigoto e Rosenaldo de Carvalho

${ }^{48}$ Eliminar os flancos, isto é, os galhos e ramos.

${ }^{49}$ Viga pequena ou fina.

${ }^{50}$ Entrevista concedida por José Gomes de Oliveira a Rosenaldo de Carvalho em 04/04/2009.

${ }^{51}$ Entrevista concedida por Delfino de Oliveira Bueno a Rosenaldo de Carvalho em 09/04/2009.

${ }^{52}$ Idem.

${ }^{53}$ Entrevista concedida por José Gomes de Oliveira a Rosenaldo de Carvalho em 04/04/2009.

${ }^{54}$ Entrevista concedida por Darci de Carvalho a Rosenaldo de Carvalho em 04/04/2009.

55 Idem.

56 Idem.

${ }^{57}$ GURSKI, Franciane. Os olhos d água e a festa de São João Maria no faxinal Palmeirinha, op. cit., p. 14.

${ }^{58}$ LE GOFF, Jacques. História e memória. Campinas: Editora da UNICAMP, 1994. p. 518.

${ }^{59}$ José Manuel Garcia Cordeiro afirma que "o ano é tido como a unidade mais longa do tempo dos homens, segundo o ritmo cíclico da terra à volta da sua fonte de luz (...) o ano litúrgico não é um calendário de festas, mas o desenrolar dos diferentes aspectos do único mistério de Cristo (...) O ano litúrgico começa no primeiro domingo do Advento e termina no sábado posterior à solenidade de Cristo Rei do Universo". Ver CORDEIRO, José Manuel Garcia. O ano litúrgico. Disponível em: <http://www.catequese.net/attachments/100_ano\%20liturgico.pdf> Acesso em 20/04/2011.

${ }^{60}$ Entrevista concedida por Palminor Brito a Rosenaldo de Carvalho.

${ }^{61}$ LOPES, José Rogério. Imagens e devoçóes no catolicismo brasileiro, op. cit., p. 13.

${ }^{62}$ ALVES, Christiane; OLIVEIRA, Gabriela; CURY, Leandro e MENDES, Mariana. A comida e o sagrado; o alimento que satisfaz o corpo e o espírito. Revista Eclética, Rio de Janeiro, ano 11, n. 22, jun-dez. 2006. p. 7. Disponível em

<http://puc-riodigital.com.puc-rio.br/media/2\%20-\%20a\%20comida\%20e\%20o\%20sagrado.pdf>

${ }^{63}$ BARBOSA, Hederson. História de São Roque. Tribuna Católica Boituvense. São Paulo, 22 de junho de 2009 . p. 1.

${ }^{64}$ Mata de Araucária (Araucária angustifolia), ou Floresta Ombrófila Mista. Apenas 1,2\% de sua cobertura original encontram-se preservados, e apenas $0,22 \%$ ( 40.774 hectares) estão sob a proteção de Unidades de Conservação (UC), o que póe em risco a preservação da floresta. Trata-se de uma cobertura vegetal característica da região sul do Brasil e das áreas elevadas da região Centro-Sul. Informação disponível em <http://www.infoescola.com/geografia/mata-de-araucarias >

${ }^{65}$ Conforme o Dicionário Histórico e Geográfico dos Campos Gerais, a identidade histórica e cultural da região dos Campos Gerais remonta ao século XVIII, quando, graças aos ricos pastos naturais, abundância de invernadas com boa água e relevo suave, foi rota do tropeirismo do sul do Brasil, com o deslocamento de tropas de muares e gado de abate provenientes do Rio Grande do Sul com destino aos mercados de São Paulo e Minas Gerais. Nessa época, os campos naturais da região tornaram-se muito disputados, e a coroa portuguesa começou a expedir cartas de sesmarias em favor de homens a ela fiéis e de prestígio político local. O ciclo do tropeirismo, que se estendeu ao início do século XX, ainda hoje tem grande influência na cultura e costumes dos Campos Gerais do Paraná, cuja população preserva muitos hábitos herdados dos tropeiros, em sua maioria de origem gaúcha. Ver LEANDRO, José Augusto (Coord.). Dicionário Histórico e Geográfico dos Campos Gerais. Ponta Grossa (PR): Departamento de História da Universidade Estadual de Ponta Grossa. Disponível em $<$ http://www.uepg.br/dicion/index.htm>

${ }^{66}$ A chamada rota dos tropeiros atravessa o estado do Paraná no sentido norte/sul, de Rio Negro, município situado na divisa com Santa Catarina, a Sengés, na divisa com o estado de São Paulo. Pesquisadores de várias áreas e investidores em turismo apontam uma variedade de atrativos que remetem aos tempos dos tropeiros.

${ }^{67}$ Assim, indica-se a capela do mosteiro Trapista, em Campo do Tenente, o mosteiro da Ressurreição e a capela Santa Bárbara do Pitangui, ambos no município de Ponta Grossa. A capela de Santa Bárbara, datada de 1727, é considerada como a primeira dos Campos Gerais. A capela Cônego José Ernser é o marco desta religiosidade em Rio Negro. No município da Lapa, existe o Parque Estadual do Monge, e em Balsa Nova, destaca-se a capela Nossa Senhora da Conceição do Tamanduá. No município de Palmeira, apresentam-se as capelinhas de Vieiras. Cf. Panorama do Turismo. Publicação de divulgação do Turismo. Novembro de 2009, p. 11-13. Disponível em <http://www.sppert.com.br/Artigos/Brasil/Paran\%C3\%A1/ Turismo/Regi\%C3\%B5es_Tur\%C3\%ADsticas/Rota_dos_Tropeiros_/>

${ }^{68}$ Exemplos de oraçóes dedicadas ao Santo:

1- São Roque, que vos dedicastes com todo o amor aos doentes contagiados pela peste, embora também a tenhais contraído, dai-nos paciência no sofrimento e na dor. São Roque proteja não só a mim, mas também aos meus irmãos e irmãs, livrando-nos das doenças infecciosas. Por isso, hoje, rezo especialmente por uma pessoa muito querida (dizer o nome da pessoa), para que fique livre do seu mal. Enquanto eu estiver em condiçóes de me dedicar aos meus irmãos, proponho-me ajudá-los em suas reais necessidades, aliviando um pouco o seu sofrimento. São Roque abençoe os médicos, fortalecei os enfermeiros e atendentes dos hospitais e defendei a todos das doenças e dos perigos. Amém. 
2- A ti, Roque, cheio de fé, te saúdo! Tu que nasceste de um sangue nobre, marcado pelo signo da Cruz, no lado esquerdo de teu flanco. Oh! Roque, que partes para o estrangeiro, curas a peste com o toque. Todos os doentes são curados ao sinal: povo rezai e bendizei! Ao grande São Roque, Glória e Esperança! Sob a inspiração da voz de um Anjo, te tornas poderoso como Deus. Curas a peste em qualquer parte.

${ }^{69}$ SILVA, Francisco Pereira da. Os Paraníadas: poema heróico do Paraná, em 12 cantos líricos. Curitiba: Centro Paranaense Feminino de Cultura, 1968, p. 23.

${ }^{70}$ Essas e outras oraçôes estão disponíveis em <http://santospadroeiros.com.br>. Nota do Editor.

${ }^{71}$ SILVA, José Júlio Cleto da. Gíria cabocla do sul do Paraná, op. cit.

72 SAHR, Cicilian Luiza Löwen e CUNHA, Luiz Alexandre Gonçalves. O significado social e ecológico dos faxinais: reflexôes acerca de uma política agrária sustentável para a região da mata com araucária no Paraná. p. 95. Disponível em <http://www.direito.caop.mp.pr.gov.br/arquivos/File/Faxinal_significado_social_ecologico_dos_faxinais.pdf> Acesso em 27/04/2011.

${ }^{73}$ Cidade localizada na região de ocorrência dos faxinais.

${ }^{74}$ ORREDA, José Maria. Aleluia. V. II. Irati, PR: Impressora Martins Ltda, 1980. p. 68.

${ }^{75}$ Um estudo sobre a utilização de plantas medicinais em medicina veterinária, realizado no município de Patos, na Paraíba, no ano de 2004, constatou que os quarenta entrevistados citaram sessenta e um tipos de plantas medicinais com as mais variadas indicaçôes terapêuticas. Nos dados obtidos dos questionários, constatou-se que 100\% dos entrevistados não só utilizavam plantas medicinais na terapêutica dos animais domésticos, como também aceitariam esta forma de tratamento como prescrição do médico veterinário. Ver MARINHO, M. L.; ALVES, M. S.; RODRIGUES, M. L. C.; ROTONDANO, T. E. F; VIDAL, I. F.; SILVA, W. W.; ATHAYDE, A. C. R. A utilização de plantas medicinais em medicina veterinária: um resgate do saber popular. Disponível em <http://www.ibb.unesp.br/servicos/publicacoes/rbpm/pdf_v9_n3_2007/artigo9_v9_n3.pdf>

${ }^{76}$ Reza recolhida por Rosenaldo de Carvalho em abril de 2011. Arquivo do Laboratório dos Faxinais.

77 Podemos pressupor que o ataque de larvas deve ter sido bastante comum, na regiáo, nos tempos anteriores ao uso dos larvicidas sintéticos, a julgar pela expressão "tempo de bicheira" que designa a época de calor e chuva, quando é comum os animais apresentarem essa doença. Ver, SILVA, José Júlio Cleto da. Gíria cabocla do sul do Paraná, op. cit.

${ }^{78}$ Entrevista concedida à Rosenaldo de Carvalho por Paulo Barros dos Santos, em abril de 2011.

${ }^{79}$ Idem.

${ }^{80} \mathrm{Idem}$.

${ }^{81}$ Idem.

${ }^{82}$ Idem.

\section{Referências bibliográficas}

ALVES, Christiane; OLIVEIRA, Gabriela; CURY, Leandro e MENDES, Mariana. A comida e o sagrado; o alimento que satisfaz o corpo e o espírito. Revista Eclética, Rio de Janeiro, ano 11, n. 22, jundez. 2006. Disponível em <http://puc-riodigital.com.puc-rio.br>

ALVES, Robinson Fernando. O monge João Maria de Agostinho em Campestre, Santa Maria: aspectos históricos. Debates do NER, Porto Alegre, ano 11, n. 17, jan.-jun. 2010.

BARBOSA, Hederson. História de São Roque. Tribuna Católica Boituvense. São Paulo, 22 de junho de 2009.

BRASIL. Decreto no. 6040, de 7/02/2007.

CAMPIGOTO, José Adilçon. A tragédia e a festa: São João da Palmeirinha, Rio Azul (PR). In: SOCHODOLAK, Hélio; ANTUNES, Jair (Orgs.). História e tragicidade. São Paulo: Scortecci, 2010.

CAMPIGOTO, José Adilçon; BONA, Aldo Nelson. A hermenêutica e a origem dos faxinais. Revista de História Regional, v. 14, n. 2, 2009.

CHAMMA, Foed Castro. Notas para um estudo da ecologia de Irati. Revista Irati-Sexagésimo aniversário do município. Irati, 1967. 
CORDEIRO, José Manuel Garcia. O ano litúrgico. Disponível em <http://www.catequese.net/ attachments/100_ano\%20liturgico.pdf> Acesso em 20/04/2011.

CÔRTES, Norma. Descaminhos do método: notas sobre história e tradição em Hans-Georg Gadamer. Varia Historia, Belo Horizonte, n. 36, v. 22, jul.-dez. 2006.

GADAMER, Hans-Georg. Verdade e método: traços fundamentais de uma hermenêutica filosófica. Petrópolis: Vozes, 1999.

GAPINSKI, Ivan; CAMPIGOTO, José Adilçon. A dança de São Gonçalo nos faxinais de Rio Azul (PR). Tempo, Espaço e Linguagem (TEL), v.1, n.3, set./dez. 2010.

GURSKI, Franciane. Os olhos d água e a festa de São João Maria no faxinal Palmeirinha. Trabalho de Conclusão de Curso (Graduação em História) - Universidade Estadual do Centro-Oeste (Unicentro), Irati, 2009.

HERMANN, Jaqueline. História das religiōes e religiosidades. In: CARDOSO, Ciro Flamarion; VAINFAS, Ronaldo (Orgs.). Domínios da história: ensaios de teoria e metodologia. Rio de Janeiro: Campus, 1997.

HOORNAERT, Eduardo. Formação do catolicismo brasileiro: 1550-1800. Petrópolis: Vozes, 1978.

JURKEVICS, Vera Irene. Os santos da igreja e os santos do povo: devoçôes e manifestaçôes de religiosidade popular. Tese (Doutorado em História) - Universidade Federal do Paraná, Curitiba, 2004.

LEANDRO, José Augusto (Coord.). Dicionário Histórico e Geográfico dos Campos Gerais. Ponta Grossa (PR): Departamento de História da Universidade Estadual de Ponta Grossa. Disponível em $<$ http://www.uepg.br/dicion/index.htm>

LE GOFF, Jacques. História e memória. Campinas: Editora da UNICAMP, 1994.

LITTLE, Paul E. Territórios sociais e povos tradicionais no Brasil: por uma antropologia da territorialidade. Brasília, Universidade de Brasília, 2002. Disponível em: <http://www.unb.br/ics/dan/ Serie322empdf.pdf> Acesso em 23 de março de 2010.

LOPES, José Roberto. Imagens e devoçóes no catolicismo brasileiro: fundamentos metodológicos e perspectivas de investigaçóes. Revista de Estudos da Religião (REVER), PUC-SP, v. 3, 2003. Disponível em www.pucsp.br/rever/rv3_2003/p_lopes.pdf 18. Acesso em 15/04/2011.

MARINHO, M. L.; ALVES, M. S.; RODRIGUES, M. L. C.; ROTONDANO, T. E. F.; VIDAL, I. F.; SILVA,W. W.; ATHAYDE, A. C. R. A utilização de plantas medicinais em medicina veterinária: um resgate do saber popular. Disponível em <http://www.ibb.unesp.br/servicos/publicacoes/rbpm/ pdf_v9_n3_2007/artigo9_v9_n3.pdf>

MELLO E SOUZA, Laura de. O diabo na terra de santa cruz: feitiçaria e religiosidade popular no Brasil colônia. São Paulo: Companhia das Letras, 1986.

MENESES, Celso Vianna Bezerra de. Religióes e práticas religiosas na região do Contestado. Tese (Doutorado em Antropologia Social) - Universidade de São Paulo, São Paulo, 2009. Disponível em <http://www.teses.usp.br/teses/disponiveis/8/8134/tde-08092009-163215/pt-br.php>

MOTT, Luiz. Cotidiano e vivência religiosa: entre a capela e o calundu. In: MELLO E SOUZA, Laura de. História da vida privada no Brasil: cotidiano e vida privada na América Portuguesa. São Paulo: Cia. das Letras, 1997. v. 1.

ORREDA, José Maria. Aleluia. V. II. Irati (PR): Impressora Martins Ltda, 1980. 
Irati. Irati (PR): Editora Sul-Oeste do Paraná Ltda., 1981.

SAHR, Cicilian Luiza Löwen; CUNHA, Luiz Alexandre Gonçalves. O significado social e ecológico dos faxinais: reflexôes acerca de uma política agrária sustentável para a região da mata com araucária no Paraná. Disponível em <http://www.direito.caop.mp.pr.gov.br>

SILVA, André Luiz da. Devoçôes populares no Brasil: contextualizando algumas obras das ciências sociais. Revista de Estudos da Religião, v. 3, 2003. Disponível em <http://www.pucsp.br/rever/rv3_2003/ p_silva.pdf>

SILVA, Francisco Pereira da. Os Paraníadas: poema heróico do Paraná, em 12 cantos líricos. Curitiba: Centro Paranaense Feminino de Cultura, 1968.

SILVA, José Júlio Cleto da. Gíria cabocla do sul do Paraná. Curitiba: Imprensa Oficial do Estado do Paraná, s/d.

SOCHODOLAK, Hélio; CAMPIGOTO, José Adilçon. Estudos em história cultural na região sul do Paraná. Guarapuava: Unicentro, 2008.

TONON, Eloy. Os monges do Contestado: permanências históricas de longa duração das predições e rituais no imaginário coletivo. Tese (Doutorado em História) - Universidade Federal do Rio de Janeiro, Rio de Janeiro, 2008. 